\title{
Formation of the Information Resource Management System of Enterprises Under the New Digital Economy
}

\author{
Viktoriia Chobitok, Tetiana Obydiennova, Yulia Us, Tetiana Demyanenko, Olena Skoromna
}

\begin{abstract}
New conditions of operation require the introduction of revolutionary and creative directions for the sustainable development of modern enterprises. The development of IT technologies, the transition to innovation and technological development is the basis for the emergence of a new format for the existence of an economic system - a new digital economy, which is qualitatively different from the classical economy, based on the use of the potential of human knowledge and the trends of vector-innovative development. The article deals with the problem of using information resources to form the basis of innovative development of business entities in the new digital economy, which is quite relevant and requires further development. The new digital economy, as a process of formation and development of the world economy in the conditions of introduction of scientific achievements and creative knowledge, has its advantages and disadvantages, which are considered in the article.
\end{abstract}

The authors consider the basic components of the new digital economy: information and communication technologies, education (fundamental and production of innovations); intellectual services (all types of business consulting, information mediation, marketing services, analytics, etc.).

The main element of the formation of a new digital economy is the use of information resources, which are the result of the interaction of the processes of functioning and automation of information systems in all spheres of functioning of market players. Each enterprise uses a large array of information resources in its activities. The authors classify the information resources of the enterprise.

In modern conditions of functioning the effective methodology of quantitative and qualitative assessment and forecasting of information resources needs has not been fully developed and tested, but it is possible to outline and scientifically substantiate the process of managing information resources by studying the information needs of the enterprise. In the work of the authorities, the system of information resources management was formed as the basis of the new digital economy.

In the course of economic activity, enterprises use technical tools to work with information resources, the amount of automation, the type and intensity of which is characterized by the essence of specific information technology.

Today, for the effective functioning of enterprises in any sector of the economy of Ukraine, it is necessary to use and research a large amount of information resources, so it is necessary to

Revised Version Manuscript Received on October 15, 2019.

Viktoriia Chobitok *, the Department Economics and Organization Business Administration, Ukrainian Engineering and Pedagogical Academy, Kharkiv, Ukraine. Email: vika_chobitok@ukr.net

Tetiana Obydiennova, the Department of Management, Ukrainian Engineering and Pedagogical Academy, Kharkiv, Ukraine.

Yulia Us Simon Kuznets Kharkiv National University of Economics, Kharkiv, Ukraine. Email: usyuliya@ukr.net

Tetiana Demyanenko, the Department Economics and Organization Business Administration, Ukrainian Engineering and Pedagogical Academy, Kharkiv, Ukraine.

Olena Skoromna, the Department of Finance of Kharkov National Agrarian University named after V.V. Dokuchaev, Kharkiv, Ukraine. involve specialists with relevant knowledge and skills in the field of ICT. The combination of knowledge, peculiarities of conducting business activities and effective management of information resources will provide an opportunity to achieve the goals and obtain an effective level of development of domestic enterprises.

The introduction of innovative digital business management systems (business operations processing), the control of production activities, the support of corporate values and the management of personnel contribute to the effective management of information resources in enterprises.

Thus, managing the information resources of business entities is a prerequisite for sustainable development and efficient management in the new digital economy.

Keywords: new digital economy, information resources, enterprises, information technologies, management.

\section{INTRODUCTION}

The current level of development of relations, as well as a clear orientation towards European integration, leads to the transition (reorientation) of economies to the information and digital space. New conditions of operation require the introduction of revolutionary and creative directions for the sustainable development of modern enterprises. The development of IT technologies, the transition to innovation and technological development is the basis for the emergence of a new format for the existence of an economic system - a new digital economy, which is qualitatively different from the classical economy, based on the use of the potential of human knowledge and the trends of vector-innovative development.

When intellectual property humanization, innovative methods of enterprise management and the global use of the results of the scientific and technological process are at the forefront of economic relations, particular attention is given to information resources, which are the basis for effective innovative development of enterprises.

\section{LITERATURE REVIEW}

The development of problems of formation and functioning of the new digital economy has been devoted to the scientific works by domestic and foreign scientists, namely: Doroshenko O.S. [1], Gudz O.E. [2], Kolot A.M. and Kravchuk O.I. [3], Belotserkivtsi V.V. [4], Marchenko O.S. [5], Goncharova S. Yu. and Buryak I.V. [6], Scotny P.V. [7 ], Turskiy I.V. and Hayda T. Yu. [8], Kolyadenko S.V. [9],

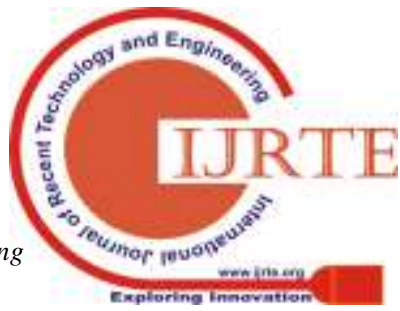


Matveychuk L.O. [10], Onischenko Yu. I. [11] and others.

However, the issue of using information resources to form the basis for innovative development of business entities in the new digital economy is quite urgent and requires further development.

\section{THE AIM OF THE PAPER}

The purpose of the article is to create a system for managing information resources of enterprises in the new digital economy.

\section{RESULTS AND DISCUSSION}

In recent years, the term "new digital economy" has become entrenched in economic science, which most scholars interpret as evolutionary changes in the structure and quality of production factors, increasing the importance of knowledge and intelligence, informatization of relationships and the introduction of innovations into real enterprise activity, and, consequently, enduring changes in methods, means and quality of management.

There are many definitions in the scientific literature of the term "new digital economy", they clearly reflect a qualitatively new format of socio-economic conditions for the development of countries, the driving factor of which is innovative transformations in various spheres of life of the population of developed countries and the world as a whole. The new digital economy, as a process of formation and development of the world economy in the conditions of introduction of scientific achievements and creative knowledge, has its advantages and disadvantages (Fig. 1).

The basic components of the new digital economy are: information and communication technologies, education (fundamental and production of innovations); intellectual services (all types of business consulting, information mediation, marketing services, analytics, etc.).

The formation of a new digital economy, as a set of qualitatively new factors for the functioning of enterprises, will help improve the process of business start-up and achieve the mission in the fastest and most efficient way.

The main element of the formation of a new digital economy is the use of information resources, which are the result of the interaction of the processes of functioning and automation of information systems in all spheres of functioning of market players. Information resources are a set of data in paper or electronic form, organized according to certain criteria and used to produce a specific result.

Information resources are transmitted verbally, in writing, or by other means (exchange of information between humans, humans and the automaton, automaton and automaton, exchange of signals in fauna and flora, transfer of signs from cell to cell, etc.). Information resources exist in time and space, passed down between generations.

Each enterprise in its activities uses a large array of information resources, the classification of which is given in Table 1.
Table 1

Classification of information resources

\begin{tabular}{|c|c|}
\hline $\begin{array}{l}\text { Classification } \\
\text { feature }\end{array}$ & Type of information resources \\
\hline $\begin{array}{l}\text { by type of } \\
\text { information }\end{array}$ & $\begin{array}{l}\text { legal; scientific and technical; political; } \\
\text { financial and economic; statistical; on } \\
\text { standards and regulations, metrology; } \\
\text { social; health care; for emergencies }\end{array}$ \\
\hline $\begin{array}{l}\text { by access } \\
\text { method }\end{array}$ & $\begin{array}{l}\text { open information (without restriction); } \\
\text { restricted access information (state } \\
\text { secrets; confidential information; trade } \\
\text { secrets; professional secrets; business } \\
\text { secrets; personal information; personal } \\
\text { (personal) secrets) }\end{array}$ \\
\hline $\begin{array}{l}\text { by types of } \\
\text { media }\end{array}$ & $\begin{array}{l}\text { on paper; on electronic media; as an } \\
\text { image on a computer screen; in the } \\
\text { computer memory; in the } \\
\text { communication channel; on other types } \\
\text { of media }\end{array}$ \\
\hline $\begin{array}{l}\text { by the way } \\
\text { storage and use } \\
\text { is organized }\end{array}$ & $\begin{array}{l}\text { traditional forms - an array of } \\
\text { documents; fund of documents; archive; } \\
\text { automated forms - Internet; data bank; } \\
\text { automated information system } \\
\text { (network); knowledge base }\end{array}$ \\
\hline $\begin{array}{l}\text { information } \\
\text { resources by } \\
\text { ownership }\end{array}$ & $\begin{array}{l}\text { state property; jointly; private property; } \\
\text { collective ownership }\end{array}$ \\
\hline $\begin{array}{l}\text { by areas of } \\
\text { formation and } \\
\text { use }\end{array}$ & $\begin{array}{l}\text { economic information, marketing } \\
\text { information, personnel information, } \\
\text { production information and more }\end{array}$ \\
\hline
\end{tabular}
${ }^{\mathrm{a}}$ - developed by the authors.

In their activities, enterprises use a large array of information resources, so the urgent issue is the formation of an information resource management system as the basis of a new digital economy. An effective methodology for quantitative and qualitative assessment and forecasting of information resources needs is not yet fully developed and tested, but it is possible to outline and scientifically substantiate the process of managing information resources by studying the information needs of the enterprise.

Management of information resources at the enterprise consists of an interdependent and necessary set of actions (Fig. 2).

In the course of economic activity, enterprises use technical tools to work with information resources, the amount of automation, the type and intensity of which is characterized by the essence of specific information technology. The purpose of information technology is to obtain the necessary information of the appropriate quality on a given medium, taking into account specifically specified limitations, including: limited cost, speed of data processing, intensity and time of use of information resource, quality of information received, etc.

Existing information technologies are elements of the information resource management system. The main functional features of the information resources management system at the enterprise are production, financial, marketing, personnel, etc. 
Taking into account the new operating conditions, the enterprises in their activity are reaching a new level of doing business. Thus, only in the last year the number of specialists having special knowledge and skills in the field of information and computer technologies (ICT) at Ukrainian enterprises has increased (Table 2,
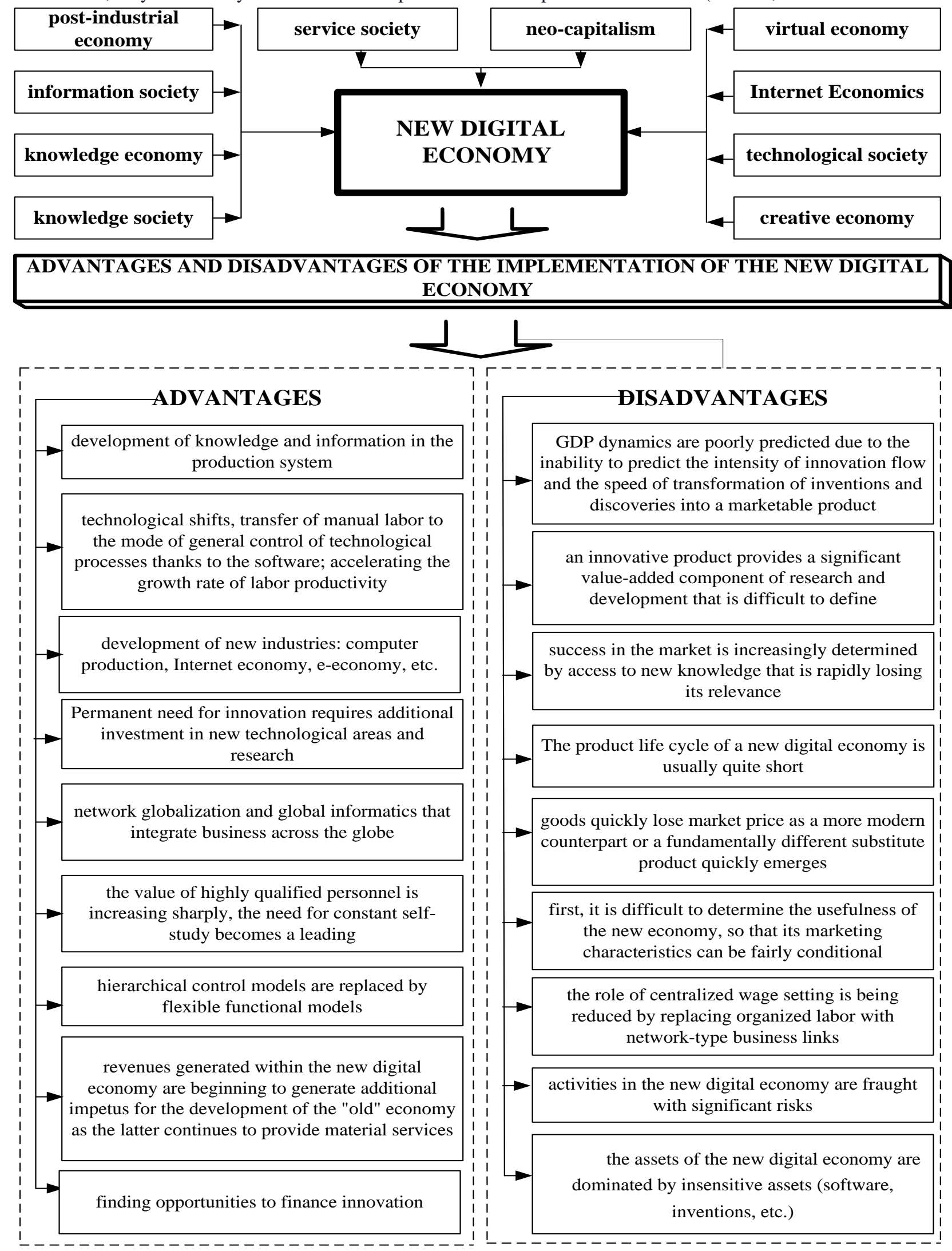

Fig. 1. The essence of the new digital economy as a process of becoming and developing the world economy 


\section{Management of information resources at the enterprise}

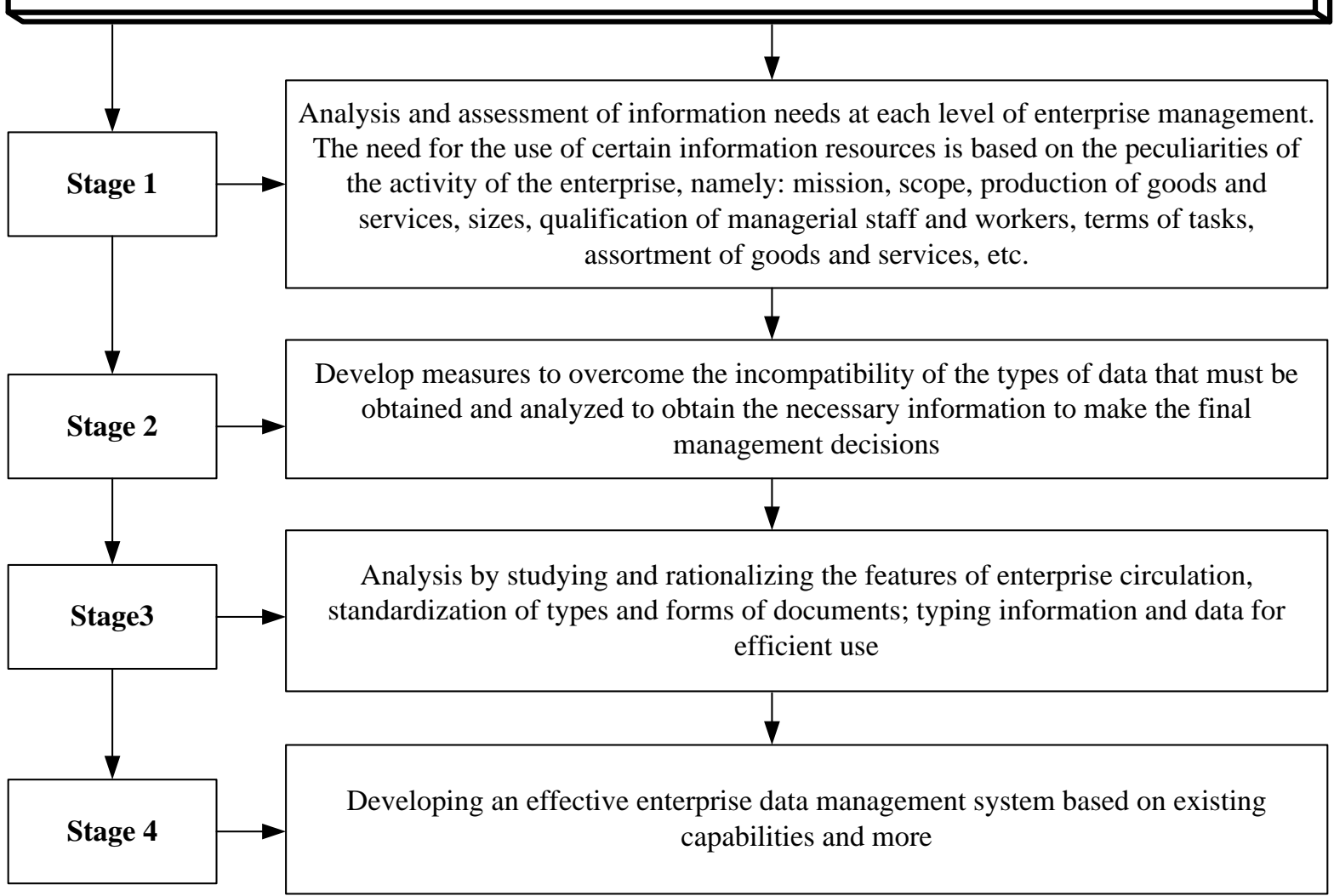

Fig. 2. Management of information resources at the enterprise

Table 2

Number of enterprises with information and communication technology specialists in different industries in $2018 *$

\begin{tabular}{|c|c|c|c|c|c|c|c|}
\hline \multirow[b]{2}{*}{$\begin{array}{l}\text { The main industries of } \\
\text { the country }\end{array}$} & \multirow{2}{*}{$\begin{array}{l}\text { Number of } \\
\text { enterprises with } \\
\text { ICT professionals } \\
\text { at the beginning of } \\
\text { the year }\end{array}$} & \multicolumn{2}{|c|}{$\begin{array}{l}\text { Number of enterprises } \\
\text { providing ICT training } \\
\text { for their employees }\end{array}$} & \multirow{2}{*}{$\begin{array}{l}\text { Number of } \\
\text { enterprises } \\
\text { engaged in the } \\
\text { recruitment of } \\
\text { ICT } \\
\text { professionals } \\
\text { during the year }\end{array}$} & \multirow{2}{*}{$\begin{array}{l}\text { Percentag } \\
\text { e of } \\
\text { enterpris } \\
\text { es that } \\
\text { trained } \\
\text { specialists } \\
, \%\end{array}$} & \multirow{2}{*}{$\begin{array}{l}\text { Percenta } \\
\text { ge of } \\
\text { enterpris } \\
\text { es that } \\
\text { trained } \\
\text { other } \\
\text { employe } \\
\text { es, \% }\end{array}$} & \multirow{2}{*}{$\begin{array}{l}\text { Percentage } \\
\text { of } \\
\text { enterprises } \\
\text { engaged in } \\
\text { the } \\
\text { recruitmen } \\
t \text { of ICT } \\
\text { profession } \\
\text { als during } \\
\text { the year, \% }\end{array}$} \\
\hline & & $\begin{array}{l}\text { training } \\
\text { courses } \\
\text { for } \\
\text { professi } \\
\text { onals }\end{array}$ & $\begin{array}{l}\text { training for } \\
\text { other } \\
\text { employees }\end{array}$ & & & & \\
\hline Manufacturing industry & 2732 & 478 & 557 & 713 & 17,50 & 20,39 & 26,10 \\
\hline $\begin{array}{l}\text { Supply of electricity, } \\
\text { gas, steam and air } \\
\text { conditioning }\end{array}$ & 251 & 46 & 55 & 74 & 18,33 & 21,91 & 29,48 \\
\hline $\begin{array}{l}\text { Water supply; sewerage, } \\
\text { waste management }\end{array}$ & 209 & 32 & 40 & 52 & 15,31 & 19,14 & 24,88 \\
\hline Construction & 608 & 73 & 119 & 146 & 12,01 & 19,57 & 24,01 \\
\hline $\begin{array}{lr}\text { Wholesale and } & \text { retail } \\
\text { trade; repair of motor } \\
\text { vehicles } & \text { and } \\
\text { motorcycles } & \\
\end{array}$ & 2918 & 470 & 573 & 780 & 16,11 & 19,64 & 26,73 \\
\hline $\begin{array}{l}\text { Transport, warehousing, } \\
\text { postal and courier } \\
\text { activities }\end{array}$ & 668 & 115 & 118 & 162 & 17,22 & 17,66 & 24,25 \\
\hline $\begin{array}{l}\text { Temporary } \\
\text { accommodation and } \\
\text { catering }\end{array}$ & 226 & 18 & 42 & 73 & 7,96 & 18,58 & 32,30 \\
\hline
\end{tabular}




\begin{tabular}{|l|l|l|l|l|l|l|l|}
$\begin{array}{l}\text { Information and } \\
\text { Telecommunications }\end{array}$ & 1274 & 293 & 178 & 571 & 23,00 & 13,97 & 44,82 \\
\hline Real estate transactions & 546 & 60 & 76 & 104 & 10,99 & 13,92 & 19,05 \\
\hline $\begin{array}{l}\text { Professional, scientific } \\
\text { and technical activities }\end{array}$ & 954 & 143 & 157 & 244 & 14,99 & 16,46 & 25,58 \\
\hline $\begin{array}{l}\text { Administrative and } \\
\text { support service activities }\end{array}$ & 555 & 69 & 100 & 147 & 12,43 & 18,02 & 26,49 \\
\hline $\begin{array}{l}\text { Provision of other } \\
\text { services }\end{array}$ & 32 & 7 & 10 & 16 & 21,88 & 31,25 & 50,00 \\
\hline Total & 10973 & 1804 & 2025 & 3082 & 16,44 & 18,45 & 28,09 \\
\hline
\end{tabular}

* according to the State Statistics Committee of Ukraine [14]

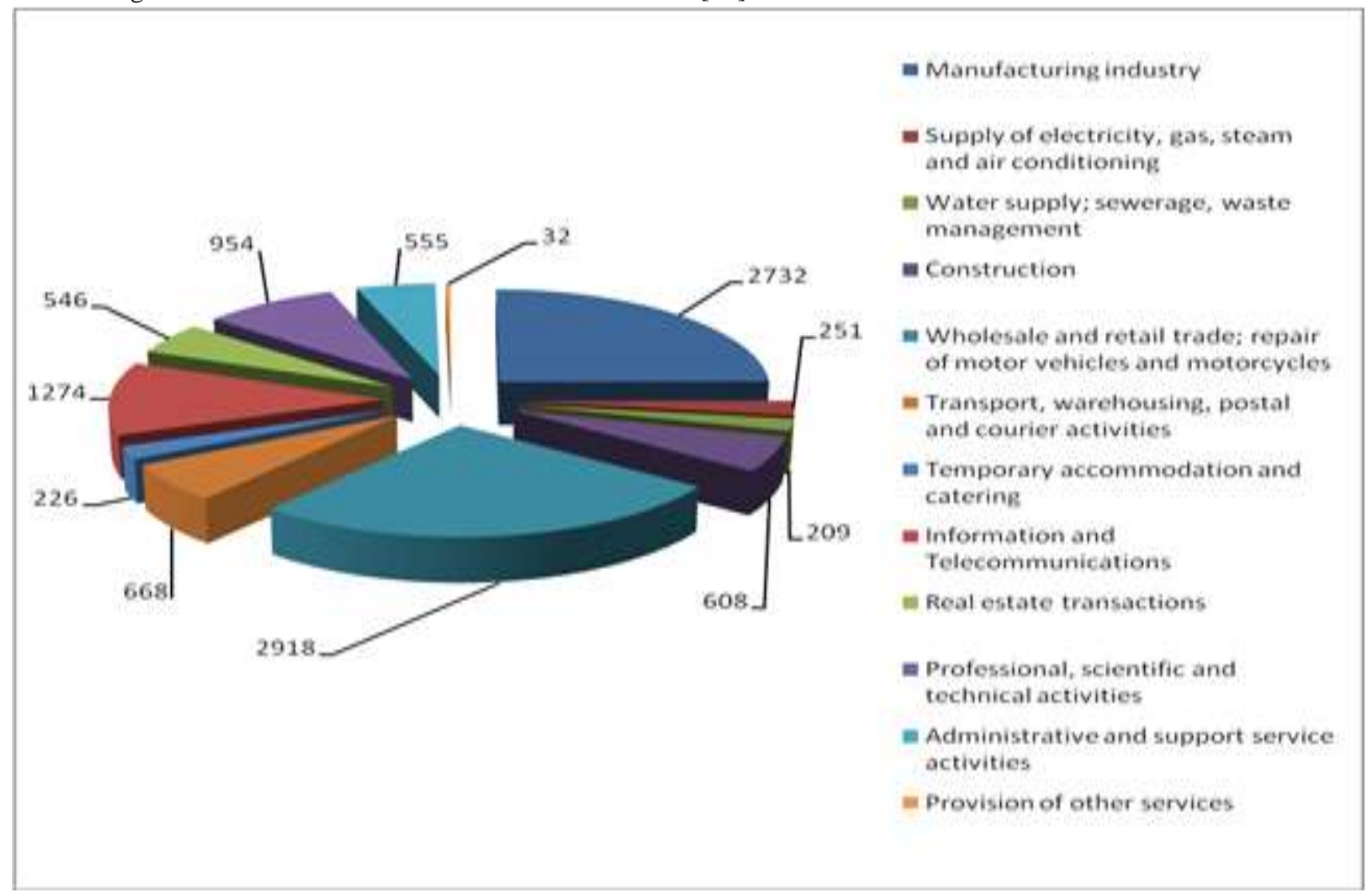

Fig.3. Structure of the number of enterprises of the main branches of economy of the country that had specialists in the field of ICT

Having analyzed the above data, we come to the conclusion that today for the effective functioning of enterprises of any branch of the economy of Ukraine it is necessary to use and research a large amount of information resources; therefore it is necessary to involve specialists with relevant knowledge and skills in the field of ICT. The combination of knowledge, peculiarities of conducting business activities and effective management of information resources will provide an opportunity to achieve the goals and obtain an effective level of development of domestic enterprises.

\section{CONCLUSION}

The economic sustainability of enterprises in the domestic and world markets largely depends on the rapid adaptation to the conditions of a turbulent environment. Achieving and consolidating a leader's position in competition depends largely on the effective use of information resources. New rules for managing the digital economy are driving evolutionary change in enterprise management. The first place is the introduction of modern technologies of management and use of information resources of the enterprise, which have integrity, exogenous nature of the structure and continuity of development.

The introduction of innovative digital business management systems (business operations processing), the control of production activities, the support of corporate values and the management of personnel contribute to the effective management of information resources in enterprises.

Thus, managing the information resources of business entities is a prerequisite for sustainable development and efficient management in the new digital economy.

\section{REFERENCES}

1 Doroshenko O. S. Ekonomi`ka znan` - bazis ekonomi`chnogo zrostannya ta ekonomi`chnogo rozvitku krayin [Knowledge Economy - the basis of economic growth and economic development of countries] // Scientific Bulletin of the Kherson State University. Ser .: Economic Sciences,. No. 17(1), pp. 27 - 31, 2016. (in Ukrainian) 
2 Gudz` O. Ye. Czifrova ekonomi`ka: zmi`na czi`nnostej ta ori`yentiri`v upravli`nnya pi`dpriyemstvami [Digital economy: changing values and orientations of enterprise management] // Economy. Management. Business.. No 2, pp.. 4 - 12., 2018 (in Ukrainian)

3 Kolot A.M., Kravchuk O. I. Lyudina i` nova ekonomi`ka: teoretiko - metodologi chnij anali z vzayemodi yi ta domi nant rozvitku [Man and the New Economy: Theoretical and Methodological Analysis of Interaction and the Dominant of Development] // Economic Theory. No 1. pp. 5 - 25, 2015. (in Ukrainian)

4 Bi`loczerki`vecz V. V. Nova ekonomi`ka: i`stori`ya ta suchasni`st` u defi`ni tivnomu vimi`ri` [New Economy: History and Modernity in the Definitive Dimension] '// Investments: Practice and Experience No 5,pp.. 9 - 13, 2015 (in Ukrainian)

5 Marchenko O. S. Nova ekonomi`ka masovoyi spi`vpraczi yak forma globali zaczi`yi ekonomi`chnoyi povedi 'nki lyudini [New economy of mass cooperation as a form of globalization of human economic behavior] // Actual problems of economy., No 4, pp. 29 - 35, 2015 (in Ukrainian)

6 Goncharova S. Yu., Buryak I. V. Umovi formuvannya ta vazheli regulyuvannya "novoyi ekonomi`ki" yak suchasnogo fenomena [Conditions of formation and levers of regulation of the "new economy" as a modern phenomenon] // Business Inform., No 3. , pp. $52-58$, 2017 (in Ukrainian)

7 Skotnij P. V. Ekonomi`ka znan`: teoretiko metodologi chnij aspect [Economy of Knowledge: Theoretical and Methodological Aspect] // European Perspectives, No. 3, pp. 163 - 169, 2017 (in Ukrainian)

8 Turs`kij I. V., Gajda T. Yu. Ekonomi`ka znan`: soczi`al`no - gumani`arni` faktori rozvitku ta regi`onal'ni` aspekti [Knowledge Economy: Social and Humanitarian Factors of Development and Regional Aspects] // Business Inform .No 8., pp. 14 - 21, 2017 (in Ukrainian)

9 Kolyadenko S. V. Czifrova ekonomi ka: peredumovi ta etapi stanovlennya v Ukrayini` i u svi ti` [Digital economy: preconditions and stages of formation in Ukraine and in the world] // Economy. Finances. Management: topical issues of science and practice. No 6 , pp. 105 - 112, 2016 (in Ukrainian)

10 Matvejchuk L. O. Czifrova ekonomi ka: teoretichni aspekti [Digital Economy: Theoretical Aspects] // Bulletin of the Zaporizhzhya National University. Economic sciences. No 4, pp. 116 - 127, 2018 (in Ukrainian)

11 Onishhenko Yu. I. Evolyuczi ya teoretichnikh pi`dkhodi`v do viznachennya sutnosti` defi`ni`czi`yi "czifrova ekonomi ka" [The evolution of theoretical approaches to the definition of the essence of the definition of "digital economy"] // Business navigator. No. 6, pp. 9 - 13, 2018 (in Ukrainian)

12 Ognyevij O. V., Ogneva A. M., Koval V. A., Prisyazhnyuk V. V. Osoblivosti upravli nnya i`nformaczi`jnimi resursami v korporativnikh ìnformaczi jnikh sistemakh [Features of information resources management in corporate information systems] // Bulletin of the Khmelnytsky National University. Engineering sciences.. No 5, pp. $17-$ 20, 2018 (in Ukrainian)

13 Matyukha M. M. Upravli`ns`kij obli`k yak element upravli`nnya i`nformaczi jnimi resursami pi`dpriyemstva [Management accounting as an element of management of information resources of the enterprise] // Black Sea Economic Studies, No 26(2)., pp. 151 - 155, 2018 (in Ukrainian)

14 Derzhavna sluzhba statistiki Ukrayini http://www.ukrstat.gov.ua

\section{AUTHORS PROFILE}

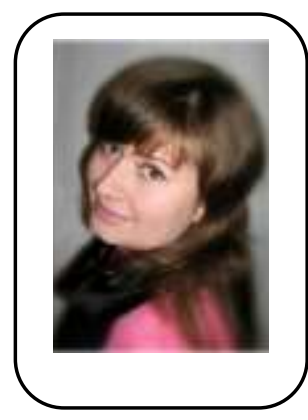

Viktoriia Chobitok - PhD of Economics, Associate Professor, Associate Professor the Department Economics and Organization Business Administration, Ukrainian Engineering and Pedagogical Academy (Kharkiv, Ukraine).

ORCID ID: 0000-0002-5272-388X

Education: Ukrainian Engineering and Pedagogical Academy (2003), Kharkiv, Ukraine. V. Chobitok has more than 100 scientific works, including 1 textbook with the stamp the Ministry Education and Science Ukraine, 12 monographs. V. Chobitok's main scientific interests are: management holistic enterprise development; potential the enterprise, innovation-investment development enterprises, competitiveness the enterprise, risks the enterprise, controlling. V. Chobitok developed the following academic disciplines: «Enterprise Economics»; «Enterprise potential»; «Economic management enterprises»; «Enterprise Resource Management».

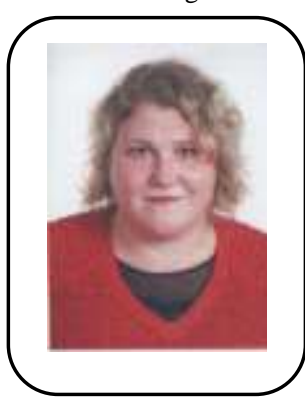

Tetiana Obydiennova - $\mathrm{PhD}$ of Economics, Associate Professor, Associate Professor Assoc. Prof. of the Department of Management, Ukrainian Engineering and Pedagogical Academy (Kharkiv, Ukraine).

ORCID ID: 0000-0002-5548-3906

She has published more than 80 scientific and methodological works. The main area of research interests are: innovation activity of enterprises, structural transformation of enterprises, corporate culture, information technologies in the management of organizations. The scientist is a member of the editorial board of the scientific professional edition «Adaptive Management: Theory and Practice. Series: Economics «(Registration in the List of Electronic Professional Editions of Ukraine: Order of the Ministry of Education and Science of Ukraine No. 693 of 10.05.2017). T. Obydiennova has completed an internship as part of the European educational project «The Innovative Methods and Technologies of Teaching: The Newest in European Education Practice» (Academia WSB) in 2019

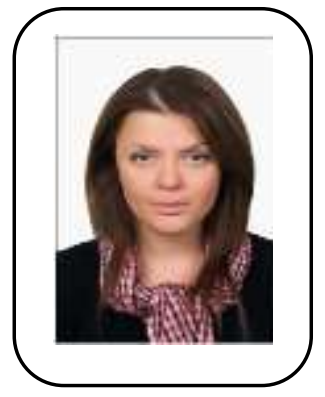

Yulia Us, PhD of Economics, Associate professor, Simon Kuznets Kharkiv Nationa University of Economics (Kharkiv, Ukraine).

ORCID - 0000-0003-2523-405X

Number of Science Interests: Anti-crisis financial management, bankruptcy and financial management, anti-crisis bank management, financial management, security, bank system, financial security. They are straightforward $\epsilon$ relevant and promising for science achievements, especially especially the problems of developing economics as a whole. The results of scientific robots are available for more than 90 scientific ones, including the number of monographs and collective monographs, the number of additional participants at conferences and scientific articles, as well as citations from international scientific databases, including numerous ones.

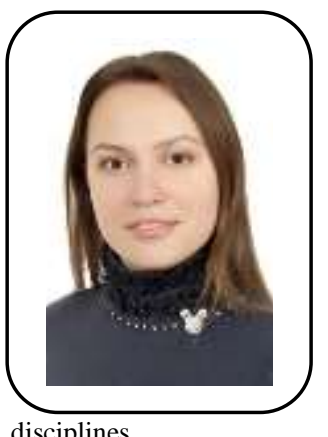

Tetiana Demyanenko - $\mathrm{PhD}$ of Economics, Associate Professor, Associate Professor of the Department Economics and Organization Business Administration Ukrainian Engineering and Pedagogical Academy (Kharkiv, Ukraine).

ORCID - 0000-0001-9362-635X

She has published over 60 scientific and methodological works. The main direction of scientific interests of $T$. Demyanenko are innovation and investment development of the enterprise. Demyanenko $\mathrm{T}$ teaches

disciplines 
"Organization of entrepreneurial activity", "Innovative development of an enterprise", "Economics of an enterprise" and others. She supervises the implementation of qualification work by students of the department. Participates in the preparation of student scientific conferences.

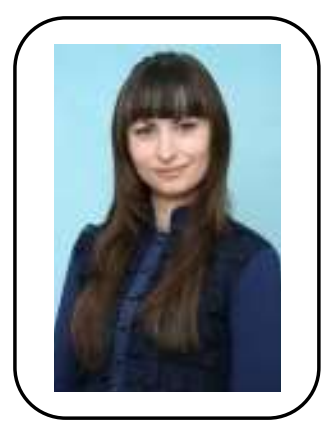

Olena Skoromna - PhD "Economics", associate professor of the Department of Finance of Kharkov National Agrarian University named after V.V. Dokuchaev. (Kharkiv, Ukraine).

ORCID ID: 0000-0002-1836-9936

She has published over 50 scientific and methodological works. The main area of scientific interests of Skoromna O. is research on the profitability of agricultural enterprises in Ukraine. Skoromna O. teaches disciplines "Enterprise Finance", "Banking System", "Taxes of the AIC" and others. Participates in the preparation of student research projects and conferences. She is responsible for the scientific work of students of the Faculty of Accounting and Finance. Skoromna O. responsible for career guidance at the faculty. 